Journal of Development and Communication Studies

Vol. 4. No. 1, January-June, 2015. ISSN (Online \& Print): 2305-7432.

http:/ / www.devcomsjournalmw.org.

(C) Journal of Development and Communication Studies, 2015.

\title{
Farmer participation in radio campaigns for technology adoption: Lessons from AFFRI's hybrid maize campaign in Mangochi, Malawi
}

\author{
Levi Zeleza Manda $(\mathrm{PhD})$ \\ Department of Journalism and Media Studies, The Polytechnic, University of Malawi. \\ Email: Imanda@poly.ac.mw

\section{Janina Wozniak(PhD)} \\ Department of Journalism, Media and Philosophy, Nelson Mandela Metropolitan University, \\ Port Elisabeth, South Africa. Email: janina.wozniak@,nmmu.ac.za
}

\begin{abstract}
This ethnographic study used focus group discussions to investigate and gather ideographical information about why statistics from the Nankumba region of Mangochi in Malawi, where, from 2008 to 2010, Farm Radio International implemented the African Farm Radio Research Initiative (AFRRI) - a meticulously and almost flawlessly planned bybrid maize variety promotion radio campaign - consistently showed that farmers preferred local to the promoted bybrid maize varieties before, during, and after the participatory community radio campaigns. The study found that in determining which maize varieties to opt for, farmers consider not only volume of yield per unit area but also taste, smell, flour extraction rate, and storability of the maize. The study further observes that preference of local maize varieties over bybrid is not restricted to rural farmers. Thus, farmer exposure to and participation in radio campaigns may increase awareness and knowledge as did the AFRRI campaign, but may not necessarily lead the farmers and consumers into adopting new maize varieties, technologies or innovations.
\end{abstract}

Key words: radio campaign, participation, radio production, adoption, innovation, bybrid maize, Malawi

Cite this article as: Manda, LZ \& Wozniak, J. 2015. Farmer participation in radio campaigns for technology adoption: Lessons from the AFRRI hybrid maize campaign in Mangochi, Malawi, Journal of Development and Communication Studies, 4(1): 2-17. DOI: $\underline{\text { http://dx.doi.org/10.4314/jdcs.v4i1.1 }}$ 


\section{Introduction}

Between 2007 and 2010 Farm Radio International, in partnership with the World University Service of Canada (WUSC), ran the African Farm Radio Initiative (AFRRI), a participatory communication action research project whose goal was to investigate how radio and modern ICTs, such as mobile phones and MP3 players, can help smallholder farmers in Africa to produce enough food for themselves, their families, and their immediate markets. Precisely, the project sought to "gather evidence on the changes [in] farmers' knowledge, attitudes, and practices as a result of specific radio programmes' (Perkins 2012:16).

Funded by the Bill and Melinda Gates Foundation, AFRRI was implemented in the five African countries of Ghana, Mali, Tanzania, Malawi, and Uganda. In each country, a country action research management and implementation team was recruited. Included in the teams were consultants or knowledge partners with expertise in specific technical and content areas of the project. Five radio stations per country (one public, one commercial, and three community or associative) were selected using criteria that included "expressed interest and commitment to producing and supporting farm radio programming, transparent and effective management, and diversity in reach across a particular region" (Ngobo and Sheila-Rao 2010:4). Prior to the implementation of the action research, Farm Radio International conducted baseline and formative studies to establish times, duration, points of radio listenership; agricultural awareness, knowledge, attitudes, practices and livelihood trajectories (Ngobo and Sheila-Rao 2010). Further, Farm Radio International trained broadcasters from selected partner radio stations in participatory radio campaign strategies and broadcast formats with the aim of ensuring that programmes were not compromised by problems associated with quality (Perkins, 2012), and gave all participating radio stations in all the five countries a computer for audio editing, Marantz field recorders and Sansa MP 3 recorders-cum-players, the Moodle software for web-based open and distance learning, and the SMS management software, Frontline SMS (Chapota 2010a). Special participatory sessions were conducted in all the targeted communities during which the project management asked the community representatives to choose two campaign themes (one for each of the projected round of the campaigns) to be promoted on radio for the benefit of the entire community. The choice was restricted to a) soil and water management, b) product diversification and c) marketing (see Manda and Chapota 2008).

In all the five participating countries, selection of agricultural technologies or improvements for radio based campaigns was done in a participatory manner, involving agriculture experts, field extension officers, chiefs, farmers, community representatives, and broadcasters, at district or sub-district level (Farm Radio International, 2011). A robust monitoring and evaluation tool was developed to compare levels of awareness, knowledge, attitudes and practices before and after the participatory radio campaigns in three types of communities, notably the Active Listening Community (ALC), Passive Listening Community (PLC), and Control Community (CC). In each country, two participatory radio campaigns were conducted on each of the five radio stations. ALC members participated as sources of radio interviews, creators of signature tunes and theme songs, choosers of radio broadcast formats, determiners of listening times and broadcast durations, and providers of feedback during the periodic monitoring and evaluation exercises. PLC members' participation was limited to listening because their areas received the radio signal. The CC members were assumed to neither have been aware of the Participatory Radio Campaign (PRC) programmes nor to have listened to the broadcasts as the CC were adjudge to be in radio signal shadow areas (Chapota 2010a). However, since community members are mobile, there is some probability that some CC members did listen to the programmes. 
As Table 1 illustrates, the participatory radio campaigns in Malawi were conducted by the Malawi Broadcasting Corporation (MBC), a public broadcasting radio which covered the Thyolo area where farmers chose strengthening management of small holder farmer organizations, associations \& cooperatives to improve access to markets for small holder farmers (campaign I) and soil management through compost manure making and application as a technology (campaign II); the Zodiak Broadcasting Station (ZBS), a commercial radio station that worked with farmers of Mvera, Dowa, who chose soil management through vetiver grass (chrysopogon rizanioids) replanting (campaign I) and compost manure application (campaign II); the Dzimwe Community Radio Station in Mangochi which promoted the planting of hybrid maize (campaign I) and composting (campaign II) as a solution to maize shortages in the area of Traditional Authority Nankumba; Nkhota Kota Community Radio which promoted the intercropping of legumes with maize (campaign I) and rehabilitation of soil through compost manure application (campaign II); and the Mudziwathu Community Radio in Mchinji which promoted the use of recommended farm inputs and compost manure (for its only campaign). Each campaign in Malawi lasted six months and, as much as possible, followed the agricultural calendar for every zone (Chapota 2010b). It is worth noting that during the second participatory radio campaign, all the radio stations chose soil and water management as their improvements to promote (see Table 1). The reason for this deviation from the original campaign plans is beyond the scope of this study.

Table 1: AFRRI Radio Campaign themes

\begin{tabular}{|l|l|l|l|}
\hline $\begin{array}{l}\text { Radio } \\
\text { Station }\end{array}$ & $\begin{array}{l}\text { Area } \\
\text { covered }\end{array}$ & Theme & \multicolumn{1}{c|}{ Improvement for Campaigns 1 \& 2 } \\
$\begin{array}{l}\text { Malawi } \\
\text { Corporation }\end{array}$ & Thyolo & $\begin{array}{l}\text { Soil \& Water } \\
\text { Management }\end{array}$ & $\begin{array}{l}\text { I. Strengthening management of small holder farmer } \\
\text { organizations, associations \& cooperatives to improve } \\
\text { access to markets for small holder farmers } \\
\text { II. Composting }\end{array}$ \\
\hline $\begin{array}{l}\text { ZODIAK } \\
\text { Broadcasting }\end{array}$ & Dowa & $\begin{array}{l}\text { Soil \& Water } \\
\text { Management }\end{array}$ & $\begin{array}{l}\text { I. Promote Vetiver grass establishment as a soil and water } \\
\text { conservation technology } \\
\text { II. Compositing }\end{array}$ \\
\hline $\begin{array}{l}\text { Dzimwe } \\
\text { Mudzi }\end{array}$ & Mangochi & $\begin{array}{l}\text { I. Product } \\
\text { Diversification } \\
\text { II. Soil \& } \\
\text { Water } \\
\text { Management }\end{array}$ & $\begin{array}{l}\text { I. Prom ote use of hybrid and improved maize varieties in } \\
\text { order to improve food security for small holder farmers } \\
\text { II. Composting }\end{array}$ \\
\hline Mchinji & $\begin{array}{l}\text { Product } \\
\text { Diversification }\end{array}$ & $\begin{array}{l}\text { 1. Promote use of recommended farm inputs such as } \\
\text { manure, seed, chemical fertilizer and pesticides to increase } \\
\text { small holder farmers' production. } \\
\text { (conducted only one campaign due to problems with } \\
\text { transmission) }\end{array}$ \\
\hline Nkhotakota & Nkhotakota & $\begin{array}{l}\text { Soil \& Water } \\
\text { Management }\end{array}$ & $\begin{array}{l}\text { I. Promote intercropping of leguminous crops as a soil } \\
\text { fertility enhancing technology } \\
\text { II. Composting }\end{array}$ \\
\hline
\end{tabular}

Source: Manda \& Chapota, 2008 
After the implementation of the two the radio campaigns, one radio station per country and the technologies it promoted were evaluated using a household questionnaire (50 from ALC, 50 from PLC, and 50 from CC; farm validation visits, lead farmer interviews, and written testimonials from lead farmers, participating broadcasters, and extension officers (Farm Radio International, 2011). The impacts of the AFRRI evaluation are summarised in Table 2.

Table 2: Reach and impact of AFRRI Radio campaigns in 3 types of communities

\begin{tabular}{|c|c|c|c|c|c|c|c|c|}
\hline Listenership & & $\%$ & \multicolumn{3}{|l|}{ Knowledge } & \multicolumn{3}{|l|}{ Practice } \\
\hline \multirow{3}{*}{$\begin{array}{l}\text { Listened to at } \\
\text { least } 50 \% \text { of } \\
\text { programmes }\end{array}$} & ALC & 82 & \multirow{3}{*}{$\begin{array}{l}\text { Demonstrated } \\
\text { good } \\
\text { knowledge of } \\
\text { PRC Practices }\end{array}$} & ALC & 70 & \multirow{3}{*}{$\begin{array}{l}\text { Started } \\
\text { Practicing } \\
\text { since PRC } \\
\text { began }\end{array}$} & ALC & 39 \\
\hline & PLC & 66 & & PLC & 52 & & PLC & 21 \\
\hline & $\mathrm{CC}$ & 0 & & $\mathrm{CC}$ & 18 & & $\mathrm{CC}$ & 4 \\
\hline
\end{tabular}

$\mathbf{N}=1,500$ per community type

Key: ALC $=$ Active Listening Community; PLC $=$ Passive Listening Community; $C C=$ Control Community; PRC $=$ Participatory Radio Campaign

\section{Source: Farm Radio International, 2011}

The above impact data suggest that the more farmers listened to radio campaign programmes, the more they learned or gained new knowledge and the more they were likely to adopt or start implementing the lessons. That may not be the case. This study sought to examine another radio campaign and compare the findings.

Since the Monkey Bay area (seat of Dzimwe community radio station) is easily accessible from Blantyre, where the author lives, the radio station and its campaigns were purposively for the task. It was assumed that if the campaigns were impactful, the area planted to hybrid maize would have increased. Secondary data tracing the planting of several maize varieties in the area were gathered. Based on the adoption patterns in Table 2, one would have expected an increase in the adoption and planting of hybrid maize validated by an increase in land dedicated to hybrid maize in the ALC and PLC communities of Nankumba/Monkey Bay, Mangochi. However, the secondary data (see Figure 1) indicate that this may not have been the case.

Figure 1: Maize Variety adoption trends in Nankumba/Monkey Bay (Mangochi), Malawi

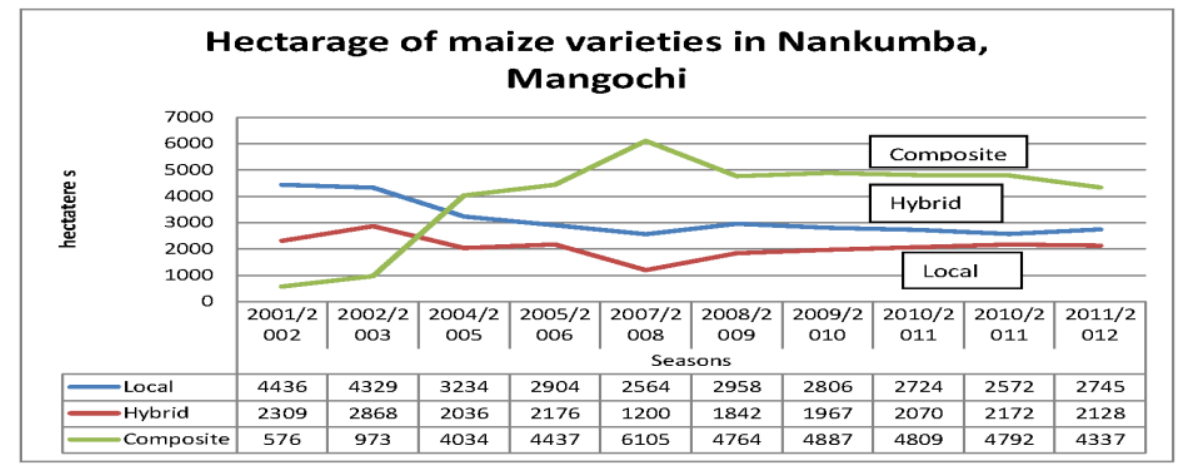

Source: Based on data provided by Mbwadrulu EPA, Mangochi, Malawi,2012 
Instead, the above data indicate that while the area planted to local maize varieties has remained virtually constant, that of hybrid maize has been dropping over the years, but adoption of composite (chamakono) varieties (crossbreeds between local maize and hybrids- also known as open pollinated varieties-OPVs) has been increasing. This suggests a continuing consumer/farmer preference trend for local maize and OPVs despite participatory radio campaign interventions. Reasons for this resistance against hybrids may lie elsewhere and only communities themselves could explain.

Writing in 1998, Smale et al. observe that, even in the 1990s when Malawian farmers planted first generation (pure) hybrids, local maize was also the most favoured, although the latter's yield per hectare area was lowest. They note that in the farming years 1991-1992 and 1994-1996, first generation hybrid maize seeds were distributed freely and the area planted to hybrid maize significantly increased. This could imply that access to hybrid seed was initially a determining factor in the adoption of hybrid maize. However, since the 2004-2005 farming year, the Farm Input Subsidy Programme (FISP) has partially solved the constraint of seed availability by providing free hybrid maize seed (again) and subsidized fertilizers (Chinsinga, 2012); which should lead to higher hybrid maize planting and production. Nonetheless, studies still indicate that despite government's infusion of these hybrid maize seeds, the adoption rate of first generation hybrids is very low in Malawi (Fisher and Mazunda, 2011), while more and more land is being dedicated to composites, which known to have a 50-70\% yield advantage over local maize (Smale and Phiri, 1998), but share a number of traits with local maize.

A study by Kassie et al. (2012) into the factors that influence the adoption of maize varieties in the Malawi districts of Mangochi and Balaka found that the majority of farmers in the area $(72 \%)$ were fully aware of the differences amongst maize seed varieties and often associated hybrid maize with high yield potential, pest/disease resistance, early maturity and drought tolerance with (Kassie et al. 2012). Despite that, only 24.8\% of the sampled households used hybrid seed, despite its known yield advantages over local (chamakolo) varieties. This shows that maize traits researchers and seed breeders consider vital to ending hunger in Malawi may not be the same as those farmers want. Further, lack knowledge and awareness about hybrids may not be a constraint and source of resistance against adoption of hybrid maize. Instead, Kassie et al. conclude that,

In Malawi, farmers tend to [dedicate more] of their land to local maize varieties under the negative sources of risk. [Even] expectation of lower yield [does not make] farmers ... change the proportion of land allocated to local varieties and if they change, they tend to increase the proportion of land planted with local varieties. Under better fertilizer and credit access, (...) they tend to allocate more land to the local maize varieties they are growing (2012, 51-52).

Thus, factors that influence farmers' choice of maize varieties in Malawi, and the Nankumba region in particular, may not have anything to do with lack access to credit, educational level, shortage of farmland, or lack of access to extension services as Kafle (2010), Kafle and Shah (2012), Carr (1997), Chipande (1987), Simtowe et al., 2009), and Katengeza et al. (2012) have severally concluded.

\section{Participation versus technology adoption}

Before discussing the factors that may influence people not to adopt hybrid maize varieties, it is worthwhile to discuss participation since the AFFRI Radio campaign informed by participatory development methodology and theory. 
Participation of target beneficiaries in the project activities has been hailed as the sine qua non for the successful implementation of development project activities and to ensure adoption of technologies and innovations. Conceived in the 1960s by, mostly, Marxists and neo-Marxist Latin American dependista, a collection of development theorists, economists, educationists, and theologians as a counter-paradigm to the then dominant modernist top-down approaches to development communication, the argument for participation has been that when people fully participate in development projects (that is, from planning through implementation to evaluation) they become empowered, own up the activities and even become agents of change, thus making social development self-sustaining (Samuels, 2005; Testafye 2011; Moosse 2011). Incredibly the role of outside agencies, the owners or representatives of the owners of the development money, is restricted to that of convenors, catalysts and facilitators (Chilinde et al. 2008).

Since then, this dependista theorisation has been virtually universalised and presently dominates third world development discourse (Berger 1995) so much so that it is perceived as a neo-colonial form of top-down development-partner/agency tyranny and imposition (Heeks 1999) hardly different from the much disdained modernist paradigm. Muniz (2011) Cooke and Kothari (2001), among other scholars, have described the current participation practice in development as merely rhetorical, ritualistic and idealistic. For Berner (2010:5), participation has failed to produce results because "there is often little willingness on the part of development agencies and experts to share effective decision making power, and consultative meetings become mere ritual to legitimise preconceived plans and to manipulate rather than facilitate the process". Consequently, Berner pronounces the participatory paradigm dead. Apropos, he writes:

The struggle for participation is over, its opponents - never numerous or vocal anyway - have unconditionally surrendered. Together with the related concepts of decentralization, good governance, empowerment and self-help, participation has become a buzzword in development debates and practice... Top-down solutions have been inappropriate - incompetent, mistargeted, insouciant and even brutal - but [the claim that] all participatory interventions are efficient and beneficial is far from reality (2010:4).

However, participation has ardent and unflinching proponents for whom any failure of a development intervention must be blamed on lack of full participation. For instance, Anyaegbnum et al. posit that among other factors, "rural development efforts fail (...) due to lack of people's participation and inadequate communication between projects and the people" (2008:7) while the FAO emphasises that "successful rural development calls for the conscious and active participation of the intended beneficiaries at every stage of the development process [because] rural development cannot take place without change in attitudes and behaviour among the people concerned" (2006:4). The FAO position also appears in the works of Tufte and Mafalopulos (2009), Servaes and Malikhao (2008), and Manyozo (2012). For Rifkin and Kangere (1990), participation of the poor and rural people in the planning, implementation and evaluation is a right and duty.

Popular participation is endorsed and hailed by most moneyed and, therefore, powerful international development agencies, such as the World Bank, DFID, the Asian Development Bank, and the African Development Bank (see Masanyiwa and Kinyashi 2008) as an important strategy or tool for rural and social development. They cite examples of successful participatory projects from around the world. Their consultants, such as Gumucio-Dagron (2001), Myers (2008) and Manyozo (2012) have compiled cases of successful participatory communications 
programmes, community radio stations, telecentres and ICT-based interventions people in Asia, Africa and Latin America.

The voices of the modernist paradigm are not completely dwarfed, nonetheless. Some researchers have identified examples of successful non-participatory development projects. Hornik (1988), for example, points out that the Village, Home and Agriculture Project in Afghanistan, the Masagana 99 in the Philippines, the Basic Village Education in Guatemala, and the Radio School Movement in Colombia succeeded despite the fact that the primary stakeholders or beneficiaries were not involved in project planning, evaluation or message production. According to Hornik (1988) the success of these projects was a direct consequence of the relevance and timeliness of the content and most importantly, in the case of Afghan Village, Home and Agriculture communication project, because the radio broadcasts followed the agriculture or farming seasons. Summing up the impact of communication for development interventions, Inagaki notes that "despite its affinity with the widely criticized modernization paradigm, [vertical or top-down] communication not only prevails in many recent communication interventions, but also proves itself a viable approach as demonstrated by many studies showing positive outcomes using such interventions" (2007:37).

To understand what constitutes full, empowering, partial, extractive or exploitative participation one needs to have recourse to Arnstein's (1969) ladder of participation, which has been refined and adapted by scholars such as Veneklassen and Miller (2002). Adapting Pretty's (1995) typology, Masanyiwa and Kinyashi (2008) classify levels of participation as follows (see Table 3):

\section{Table 3: Ladder of participation}

\begin{tabular}{|c|c|}
\hline Level & Characteristies of each type \\
\hline $\begin{array}{l}\text { 1. Passive } \\
\text { Participation }\end{array}$ & $\begin{array}{l}\text { People participate by being told what is going to happen or has } \\
\text { already happened. It is a unilateral announcement by leaders or } \\
\text { project management without listening to people's responses or even } \\
\text { asking their opinion. }\end{array}$ \\
\hline $\begin{array}{l}\text { 2. Participation in } \\
\text { Information } \\
\text { Giving }\end{array}$ & $\begin{array}{l}\text { People participate by answering questions posed by extractive } \\
\text { researchers using questionnaire surveys or similar approaches. } \\
\text { People do not have opportunity to influence procedings, as the } \\
\text { findings of the research are neither shared nor cheoked for accuracy. }\end{array}$ \\
\hline $\begin{array}{l}\text { 3. Participation by } \\
\text { Consultation }\end{array}$ & $\begin{array}{l}\text { People participate by being consulted, and external people listen to } \\
\text { views. These external professionals define both problems and } \\
\text { solutions, and may modify these in light of people's responses. Such } \\
\text { a consultative process does not concede any share in decision- } \\
\text { making, and professionals are under no obligation to take on board } \\
\text { people's views. }\end{array}$ \\
\hline $\begin{array}{l}\text { 4. Participation for } \\
\text { Material } \\
\text { Incentives }\end{array}$ & $\begin{array}{l}\text { People participate by providing resources, for example labour, in } \\
\text { return for food, cash or other material incentives. It is very common } \\
\text { to see this called participation, yet people have no stake in } \\
\text { prolonging activities when the incentives end. }\end{array}$ \\
\hline $\begin{array}{ll}\text { 5. } & \text { Functional } \\
\text { Participation }\end{array}$ & $\begin{array}{l}\text { People participate by forming groups to meet predetermined } \\
\text { objectives related to the projeet, which can involve the development } \\
\text { or promotion of extemally initiated social organisation. Such } \\
\text { involvement does not tend to occur at the early stages of project } \\
\text { cycles or planning, but rather after major decisions have been made. } \\
\text { These institutions tend to be dependent on external initiators and } \\
\text { facilitators, but may become self-dependent. }\end{array}$ \\
\hline $\begin{array}{l}\text { 6. Interactive } \\
\text { Participation }\end{array}$ & $\begin{array}{l}\text { People participate in joint analysis, which leads to action plans and } \\
\text { the formation of new local institutions or the strengthening of } \\
\text { existing ones. It tends to involve interdiseiplinary methodologies } \\
\text { that seek multiple perspectives and make use of systematic and } \\
\text { structured learning processes. These groups take control over local } \\
\text { decisions, and so people have a stake in maintaining structures or } \\
\text { practices. }\end{array}$ \\
\hline 7. Self-Mobilisation & $\begin{array}{l}\text { People participate by taking initiatives independent of external } \\
\text { institutions to change systems. They develop contacts with external } \\
\text { institutions for resources and technical advice they need, but retain } \\
\text { control over how resources are used. Such self-initiated mobilisation } \\
\text { and collective action may or may challenge existing inequitable } \\
\text { distributions of wealth and power. }\end{array}$ \\
\hline
\end{tabular}

Source: Masanyiwa and Kinyashi, 2008 
The literature on participatory development approaches indicates that only types 6 and 7 constitute true or full participation because interactive participation and self-mobilisation empower the beneficiary communities to identify what is good for their lives, how they can achieve it and measure its success (see Figueroa et al. 2002). The rest of the participation categories are deemed to amount to pseudo-participation (Carpentier and De Cleen 2008; or tokenism (Arnstein 1969; Manyozo 2012), exploitative participation (Berner 2010) or partial participation (Pateman 1970). Pateman (1970) defines partial participation as a "process in which two or more parties influence each other in the making of decisions, but the final power to decide rests with one party only" (1970 cited by Carpentier and De Cleen, 2008:2). In brief, development interventions will fail unless it allows for popular interaction or self-mobilisation. But, could this explain the dismal performance of the hybrid maize adoption campaign under study?

\section{Research Design}

\section{Goal and research questions}

This study sought to answer three related research questions (RQ), notably:

RQ 1: Are smallholder farmers aware of the different traits of the maize cultivars planted in Malawi?

RQ 2: What factors influenced the farmers of the Nankumba region, Monkey Bay, Malawi to choose maize cultivars before, during, and after the AFRRI radio campaign to promote the technology?

RQ 3: Why did farmer participation in radio campaigns not influence targeted farmers to adopt hybrid maize varieties?

\section{Method}

As previously indicated, the study reviewed secondary data on the rate of adoption of maize (measured in amount of farmland allocated to each variety before, during and after the AFRRI participatory radio campaign). The secondary data on maize hectarage, spanning the period 2001/2 to 2011/12 farming seasons, were provided by the Ministry of Agriculture's Mbwadzulu Extension Planning Office in Mangochi (Figure1). From the maize hectarage data, a trend pattern was computed using the XL Data Analyst, an MS Excel add-on that functions like the Statistical Package for Social Scientists (SPSS). Thereafter, 32 farm family heads or household representatives in the villages of Msumbi II (17) and Chigonere (15), both of which had participated in the AFRRI hybrid maize promotion in 2008/9, were systematically selected and interviewed in the local Chichewa language, on 27 April, 2012, using the focus group discussion (FGD) interviewing format. The FGDs were held in two geographically separate sessions for approximately two hours each. The two Focus Group Interviews were tape-recorded, transcribed and analysed using meaning condensation or thematisation techniques proposed by Kvale (1996). Although the researcher was accompanied to the two communities by an extension officer from Mbwadzulu EPA, which oversees agriculture activities in the Nankumba region of Mangochi, the officer did not participate in the discussions to avoid his presence influencing the discussions. The focus group discussions were preferred to other methods of inquiry because these have been known to elicit ideographic information that provides rare insights into human behaviours and beliefs (Holliman 2005) that in turn influence individual 
and societal tastes. To check if the reasons were unique to rural-based maize farmers-cumconsumers, 14 purposively selected urban-based educated (elite) maize-nsima eating people were also interviewed through email during the second week of June 2012 about their maize variety preferences.

\section{Ethical consideration}

In keeping with the requirements of Malawi's National Commission for Science and Technology research clearance guidelines for the social sciences and humanities (NCST, 2011) and the Nelson Mandela Metropolitan University Higher Degrees Research Clearance (Ref: H/10/ART/JMS-003) requirements, all FGD participants and extension officers involved in data provision were informed about the nature and goal of the study and that they were free to stop participating in the study at any time without any reprisal. The interviews were conducted in Chichewa, the most commonly spoken language of the Monkey Bay area in Malawi.

\section{Findings and Discussion}

\section{RQ 1: Are farmers aware about the different traits of maize cultivars?}

The focus group discussions at Msumbi II (coded as MS) and Chigonere (CG) reveal a number of issues about how smallholder farmers perceive and choose varieties of maize for planting and consumption. The first is that in both communities, farmers are aware about the differences between local maize (chamakolo), hybrid maize (bybrid), and composite (OPVs) maize (chamakono) probably because of the information they get from agricultural radio programming from radio and through on-farm extension activities. In both areas, the members of the Focus Group Discussions (FGD) recalled that even before the AFFRI participatory radio campaign, there was another campaign, funded by the Sasakawa Global 2000, on planting hybrid maize using the one-plant-per-station method (chimodzimodzi or sasakawa), such that the AFRRI participatory radio campaign was nothing new to the community.

RQ 2: What factors influenced the farmers of the Nankumba region, Monkey Bay, Malawi to choose maize cultivars before, during, and after the AFRRI radio campaign to promote the technology?

\section{Why farmers resist hybrid maize}

The Guide to Agricultural Production and Natural Resources Management in Malawi (Malawi Government n.d.) encourages farmers to plant modern maize (pure hybrid and OPV) because it is, inter alia, higher yielding (maximum of $10,000 \mathrm{~kg} / \mathrm{ha}$ ) than local maize (maximum of 3,000 $\mathrm{kg} / \mathrm{ha}$ ). However, the FGDs indicate that high yield is not the only trait that farmers look for in maize. The discussion at Chigonere even disputed the claim that hybrid seeds yield more than local maize, as the excerpt below illustrates (CG 10 means participant number in the Chigonere FGD speaks, etc):

CG10: I don't believe that hybrids are higher yielding than local maize. Last year, I divided my field into two. In one part, I planted local maize using the Sasakawa method (one seed per station). I planted hybrid maize in the other part. I applied [chemical] fertilisers to both. But, in the local maize section most stalks had two cobs while almost all stalks in the hybrid maize section had only one cob.

Moderator: Are you sure about that? 
CG5: I also planted hybrid maize. My maize stalks had just one cob each.

CG10: We know that local maize weighs more than hybrid. So why should people claim that hybrid maize yields more? I need evidence.

Moderator: What is the name of hybrid seed you planted?

CG 10: I cannot remember.

Moderator: Next time try different types.

\section{Maize traits preferred by local farmers and consumers}

Table 4 compares local and hybrid maize variety traits using the official description (Malawi Government, n.d) and Focus Group Discussants' perceptions.

Table 4: Maize traits: Malawi government versus farmer perceptions

\begin{tabular}{|c|c|c|c|c|}
\hline & \multicolumn{2}{|c|}{ Local varieties } & \multicolumn{2}{|l|}{ Hybrids } \\
\hline Factor/Trait & Official description & $\begin{array}{l}\text { Local } \\
\text { community } \\
\text { description }\end{array}$ & $\begin{array}{l}\text { Official } \\
\text { description }\end{array}$ & $\begin{array}{l}\text { Local } \\
\text { community } \\
\text { experiences }\end{array}$ \\
\hline Yield & Low yielding & $\begin{array}{l}\text { Low yielding } \\
\text { (chosathetsa } \\
\text { njala) }\end{array}$ & High yielding & Non-committal \\
\hline $\begin{array}{l}\text { Pest/disease } \\
\text { resistance }\end{array}$ & $\begin{array}{l}\text { Lack of pest/disease } \\
\text { resistance }\end{array}$ & $\begin{array}{lr}\text { Resistant } & \text { to } \\
\text { pests } & \text { and } \\
\text { diseases } & \end{array}$ & $\begin{array}{ll}\text { Resistant } & \text { to } \\
\text { pest/disease }\end{array}$ & $\begin{array}{l}\text { Resistance at a } \\
\text { cost Expensive: } \\
\text { requires } \\
\text { pesticides }\end{array}$ \\
\hline Storage & Easy to store & Easy to store & $\begin{array}{l}\text { Easy to store } \\
\text { when properly } \\
\text { treated }\end{array}$ & $\begin{array}{l}\text { Difficult to } \\
\text { store: requires } \\
\text { pesticides }\end{array}$ \\
\hline $\begin{array}{l}\text { Flour } \\
\text { extraction } \\
\text { ratio }\end{array}$ & Not available & $\begin{array}{l}\text { High grain-flour } \\
\text { extraction }\end{array}$ & Not available & $\begin{array}{l}\text { Low grain-flour } \\
\text { extraction }\end{array}$ \\
\hline Maturity & Late & Late & Early & Early \\
\hline $\begin{array}{l}\text { Tolerance to } \\
\text { low/erratic } \\
\text { rainfall }\end{array}$ & Not tolerant & Not tolerant & Tolerant & Tolerant \\
\hline Seed & Recyclable & Recyclable seed & Non-recyclable & Non-recyclable \\
\hline $\begin{array}{l}\text { Labour and } \\
\text { expenses }\end{array}$ & $\begin{array}{l}\text { (Information not } \\
\text { available }\end{array}$ & Reasonable & $\begin{array}{l}\text { Information not } \\
\text { available }\end{array}$ & $\begin{array}{l}\text { Requires heavy } \\
\text { fertilisation } \\
\text { Labour } \\
\text { intensive } \\
\text { (shelling, drying } \\
\text { before storage) }\end{array}$ \\
\hline Quality & $\begin{array}{l}\text { Information } \\
\text { available }\end{array}$ & $\begin{array}{l}\text { Tasty fresh or } \\
\text { cooked } \\
\text { Attractive grain } \\
\text { appearance } \\
\text { Flour lasts long } \\
\text { (e.g. one } 50 \mathrm{~kg} \\
\text { bag may last a } \\
5 \text {-member } \\
\text { household more } \\
\text { than month). } \\
\text { mone }\end{array}$ & High quality & $\begin{array}{l}\text { Tasteless } \\
\text { Unattractive } \\
\text { appearance } \\
\text { Low quality } \\
\text { flour } \\
\text { Flour does not } \\
\text { last long (e.g. } \\
\text { one } 50 \mathrm{~kg} \text { bag } \\
\text { may last a } 5- \\
\text { member } \\
\text { household less } \\
\text { than a month) } \\
\text { Quick } \\
\text { digestion/not } \\
\text { satisfying (nsima } \\
\text { yake sikhalitsa } \\
\text { m'mimba) }\end{array}$ \\
\hline
\end{tabular}

Source: Manda \& Wozniak-Focus Group Discussions, 2012 
It is clear from the above table that overall, farmers appreciate that hybrid maize is quick maturing and tolerant to low or erratic rainfall, which makes it suitable to avert hunger in low rainfall or rain shadow areas such as Nankumba in Mangochi, Malawi. However, the farmers find hybrid maize farming expensive, because, in their opinion, it requires heavy chemical fertiliser and pesticide application, and it is labour intensive as it requires early harvesting, home-drying, and shelling before storage in modern (metal) silos. Further, hybrid maize is disdained for being non-recyclable as seed.

Other reasons for farmer reluctance to adopt hybrid maize include the low grain-flour extraction rate (too much bran), tastelessness (when eaten green or as nsima), unattractive smell, unattractive appearance of grain, low quality flour, and uneconomical (requires huge amounts of flour to prepare nsima but it quickly digests away. The discussants explained that 'quick digestion' is an issue because in rural areas, most families have one or two meals per day. As such, a 'heavy meal' that does not 'quickly [get digested away] and leave you feeling hungry before the next meal' (MS 4) is a necessity and an integral part of household food security.

\section{Maize traits preferred by elite urban consumers}

Perceptions of the inferiority of hybrid to composite and local maize may not be restricted to rural illiterate farmers. Table 5 shows preferences of elite maize consumers, which were gathered through email interviews. Of the 14 people who responded, one was non-committal, but the rest (13) indicated their preferences. Interviewees were free to give as many reasons as they wished. Like among rural farmers of Nankumba, Mangochi, the preference among the elite maize consumers is for local maize varieties (chamakolo). It would appear that even amongst the elite urban Malawian consumers, maize taste and beauty matter. It would appear local maize is preferred because its flour 'lasts long'.

Table 5: Maize traits preferred by elite consumers

\begin{tabular}{|c|c|c|}
\hline Reason & $\begin{array}{|lr|}\mathrm{N}=14 & (8 \\
\text { male; } & 6 \\
\text { female }) & \\
\end{array}$ & $\%$ \\
\hline Tastier than hybrid (as nsima or green snack) & 12 & 85 \\
\hline Long lasting flour & 6 & 42.9 \\
\hline Good for seed biodiversity & 2 & 14.2 \\
\hline Pest/disease resistance & 3 & 21.4 \\
\hline Nice Smell & 3 & 21.4 \\
\hline Good appearance of grain & 1 & 7.1 \\
\hline $\begin{array}{l}\text { Poundability (in mortar or maize mill to remove } \\
\text { bran) }\end{array}$ & 1 & 7.1 \\
\hline Fulfilling/Satisfying/stomach filling & 1 & 7.1 \\
\hline Non-committal & 1 & 7.1 \\
\hline
\end{tabular}

Source: Manda \& Worniak-Online interviews, 2012 
RQ 3: Why did farmer participation in radio campaigns not influence targeted farmers to adopt hybrid maize varieties?

The FGD participating farmers were asked to explain why they did not adopt the hybrid maize varieties yet they were part of the people that participated in the technology selection and radio campaign design process, during which the promotion of hybrid maize farming was prioritized. After a long a silence one person in the Msumbi II FGD said,

The problem is that we did not have a variety of choices to pick from. Only three areas (improvements) were given to us. So, we picked hybrid maize planting because kukana nsalu yakulu nkubviika (we accepted out of fear of reprisals). Besides, you people rarely consider our views. If we had asked you to promote tomatoes instead of hybrid maize would you have accepted? (MS 7).

\section{Sources of popular resistance to hybrid maize}

Statistics presented in Figure 1 indicate that despite financial investment in media campaigns for the adoption of hybrid maize, there appears to be some resistance in the Nankumba region of Mangochi, Malawi. In general, community members still prefer maize that is tasty, easy to store, can be pounded to remove the bran, and whose seed is recyclable. Although they yield less than hybrids, composite maize seeds (chamakono) present the middle ground traits between local maize (chamakolo) and hybrids. Their seed is recyclable for up to three farming seasons (Makiyi 2012); they are poundable (chokonoka), provide higher flour-to-grain extraction rates, and are easier to store than hybrids. Aesthetically, composite maize is considered better tasting and more attractive than hybrids although composites are perceived to be inferior to local maize. These findings endorse those from Smale et al. (1991) and Chinsinga (2012). An empirical study by Fisher and Mazunda also found that "farmers perceive modern maize varieties from a production standpoint (high yield), but [...] favour local varieties from a consumption point of view (nice taste)" (2011:1). In their study on adoption of maize varieties in Mulanje, Malawi, Fisher and Mazunda (2011) and Lunduka, Fisher and Snapp (2012) found that the researchers the farmers interviewed liked hybrid maize because it was high yielding, drought tolerant, early maturing whereas they liked local and composite varieties for their storability, "poundability", high flour-to-grain extraction rate, and good taste. These findings also resonate with those from Kumar (1994), who noted that difficulty in storage and 'unusual' taste drove farmers in Eastern Zambia to prefer local maize to first generation (or pure) hybrid maize.

Another reason why the radio campaign did not succeed hides in the word of FGD participant MS 7. As it has been noted earlier, local communities were asked to choose from three themes. The narrowness of the choice range could have forced the community to choose maize against other yet to be revealed choices. While the AFRRI radio campaigns invested many resources in making communities participate, they were not participatory enough engender adoption of hybrid maize. The fact that a similar campaign had been implemented in the area without much success could have made the AFFRI management to recast their campaigns from creating awareness and knowledge to addressing the deep-rooted perceptions and attitudes about maize. 


\section{Conclusion}

The results of this study seem to point to the fact that farmer participation in nor or access to radio campaigns may not necessarily lead to adoption of innovations by farmers. If the community in Monkey Bay had been completely free to choose which maize variety or another food security technology to promote, it is likely that the radio could have concentrated on something else. As the second campaign illustrates, soil health was a more serious issue across the five participating radio stations than hybrid maize promotion and other subjects that were identified for campaigns; which means that the first campaign was a waste of resources. It is thus important for future radio campaign designers to fully understand the background information about the target community and promote only the crops or technologies that the community wants. Also, it is important to identify issues that might militate against adoption of crops or technologies being promoted well before the campaign is launched. Had this approach

been pursued, the Dzimwe Community Radio campaign would have targeted moderation of societal dislike for hybrid maize rather than mere increase in productivity.

\section{Acknowledgements}

The authors acknowledge research funds provided by the Research Capacity Development Department of the Nelson Mandela Metropolitan University (NMMU), Port Elisabeth, South Africa (Ref. H/10/ART/JMS-003), which enabled them to conduct field research in Malawi. Secondary data cited in this paper were obtained from the Ministry of Agriculture's Mbwadzulu Extension Planning Area (EPA) office in 2012 with the due permission of the EPA authorities.

\section{References}

Berger, G. (1995)

Developers and Communication in South Africa: Background article for training course: Managing Development in the New South Africa. http://guyberger.ru.ac.za/Research/Democracy/index.htm. (Accessed 19 November 2012)

Berner, E. 2010.

Participation: Between Tyranny and Emancipation. In Gomez, G.M., Corradi, A.A., Goulart, P. \& Namara, R. (eds.) Participation for what: Social change or social control? (pp.13-24). The Hague: ISS/Erasmus University

Rotterdam/HIVOS/Oxfam Novib

Carr, S.J. 1997.

A green revolution frustrated: lessons from the Malawi experience. African Crop Science Journal, 5(1): 93-98

Chapota, R. 2010a.

The African Farm Radio Research Initiative: Working with Radio stations and Smallholders Farmers in Malawi: Experiences and Lessons Learnt. Paper presented at the $1^{\text {st }}$ Farm Radio Symposium, Lilongwe, Malawi (5 August). 
Chapota, R. 2010b.

AFRRI Malawi Agricultural Improvements/Technologies for the $2^{\text {nd }}$ participatory radio campaigns in five the five partner stations starting from September 2009. Paper presented at the $1^{\text {st }}$ Farmer Radio Symposium, Lilongwe, Malawi (5 August).

Chilinde, G., Ntata, P. \& Chipeta, L. 2008.

Participation in Community Driven Development Among Urban Poor: The Case of Lilongwe City. In Kamlongera, C. (ed.), Challenges in Promoting Community Driven Development (pp.180-216). Lilongwe: MASAF.

Chinsinga, B. 2012.

Seeds and Subsidies: The Political Economy of Input Support Programmes in Malawi. Future Agricultures Policy Brief. http://www.futureagricultures.org/blog/entry/the-future-of-the-farm-input-subsidy-programmefisp-a-political-economy-inquiry\#.US3wIzBTCSo. (Accessed 11 January, 2013)

Chipande, G.H.R. 1987.

Innovation Adoption among Female-headed Households: the Case of Malawi. Development and Change, 18 (2):315-327.

Farm Radio International. 2011.

Participatory Radio Campaigns and Food Security: How radio can help farmers make informed decisions. http://www.farmradio.org/wp-content/uploads/farmradioprcreport20111.pdf. (Accessed 11 November 2014)

Fisher, M. \& J. Mazunda. 2011.

'Could low adoption of modern maize varieties in Malawi be explained by farmers' interest in diverse seed characteristics?' Malawi Strategy Support Programme (Policy Note 7). International Food Policy Research institute (IFPRI). http://ebrary.ifpri.org/cdm/singleitem/collection/p15738coll2/id/126162/rec

Heeks, R. 1999. L7. (Accessed 11 February 2013).

The Tyranny of Participation in Information Systems: Learning from Development Projects. http://www.man.ac.uk/idpm dp.htm\#devinf wp. (Accessed 15 January 2015)

Hornik, R. 1988.

Development Communication: Information, Agriculture and Nutrition in the Third World.

New York: Longman.

Inagaki, N. 2007.

Communicating the Impact of Communication for Development: Recent Trends in Empirical Research. Washington, DC: The World Bank.

Kafle, B \& P. Shah. 2002.

Adoption of Improved Potato Varieties in Nepal: A case of Bara district. Journal of Agricultural Sciences, 7(1):14-22

http://www.sljol.info/index.php/JAS/article/view/4063/3311. (Accessed 10 August 2012).

Kafle, B. 2010.

Determinants of adoption of improved maize varieties in developing countries: A review. International Research Journal of Applied and Basic Sciences. 1(1):51-59. 
Kassie, G.T., Erenstein, O. Mwangi, W. LaRovere, R. Setimela, P. \& Langyintuo. A. 2012. Characterization of Maize Production in Southern Africa: Synthesis of CIMMYT/DTMA Household Level Farming System Surveys in Angola, Malawi, Mozambique, Zambia and Zimbabwe. Mexico: International Maize and Wheat Improvement Centre.

Kumar, S. 1994.

Adoption of Hybrid Maize in Zambia: Effects on Gender Roles, Food Consumption and

Nutrition (Research Paper No.100). Washington: International Food Policy

Research Institute.

Kvale, S.1996.

InterViews: An Introduction to Qualitative Research Interviewing. London: SAGE.

Lunduka, R., M. Fisher \& S. Snapp, S. 2012.

Could farmer interest in a diversity of seed attributes explain adoption plateaus

for modern maize varieties in Malawi?' Food Policy. 37(5):504-510.

http://www.sciencedirect.com/science/article/pii/S0306919212000528.

(Accessed 11 December 2012)

Makiyi, F. 2012 (11 June).

Personal Communication interview

Malawi Government. (n.d).

Guide to Agricultural Production and Natural Resources management in Malawi.

Lilongwe: Ministry of Agriculture, Irrigation, and Food Security.

Manda, L.Z. \& Chapota, R. 2008.

AFFRI Campaign Design Workshop Report.

http://www.academia.edu/4438816/AFRRI_Campaign_Design_Workshop_Report.

(Accessed 22 December 2014)

Manyozo, L. 2012.

People's Radio: Communicating Change across Africa. Penang: Southbound

Masanyiwa, Z.S \& Kinyashi. G.F. 2008.

Analysis of Community Participation in Projects Managed by Non-

Governmental Organisations: A Case Study of World Vision in Central

Tanzania.

http://www.eldis.org/vfile/upload/1/document/0806/Analysis $\% 20$ of $\% 20$ com

munity $\% 20$ participation.doc. (Accessed 22 April 2014)

Mazunda, J. \& Droppelmann, K. 2012.

Maize Consumption Estimation and Dietary Diversity Assessment Methods in

Malawi. Malawi Strategy Support Programme' (Policy Note 11). International

Food Policy Research institute (IFPRI).

http://www.ifpri.org/sites/default/files/publications/massppn11.pdf.

(Accessed 11 February 2013)

Moose, D. 2011.

The Making and Marketing of Participatory Development. In Cornwall, A. (ed.). The

Participation Reader, (pp.182-2002). London: Zed Books

Myers, M. 2008.

Radio and Development in Africa -A Concept Paper Prepared for the IDRC.

http://r4d.dfid.gov.uk/pdf/outputs/ict4d/radio and development in africa c oncept paper.pdf. (Accessed 13 December 2012)

National Commission for Science and Technology (NCST). 2011. 
The Framework of Requirements of requirements and guidelines for research in the social sciences and bumanities in Malawi. http://www.ncst.mw/wp-

content/uploads/2014/03/NATIONAL-FRAMEWORK-OF-

REQUIREMENTS-AND-GUIDELINES-IN-SSH.pdf. (Accessed 11 May 2014)

Ngobo, M. \& Huggings-Rao, S. 2010.

Radio For Farmers: The African Farm Radio Research Initiative's Approach to

Strengthening Agriculture and Food Security Radio Programmes. Paper

Perkins, K. 2012 presented at the $1^{\text {st }}$ Farm Radio Symposium, Lilongwe, Malawi (5 August)

Participatory Radio Campaigns and Small-Scale Farming Innovations:

Promoting Learning and Uptake. In Pringle, I, Mittal, E. and Valdés, M.(eds.).Public Learning with Community Media: Stories from the Commonwealth and Latin America, 15-22. British Columbia: Commonwealth of Learning.

Rifkin, S. B. \& Kangere, M. 2001.

What is Participation? In Hartley, S. (ed.). CBR: A Participatory Strategy in Africa, (pp. 37-49). London: Centre for International Child Care.

http://www.asksource.info/cbr-book/cbr03.pdf. (Accessed 15 May 2015)

Samuels, J. (ed.). 2005.

Removing Unfreedoms: Citizens as Agents of Change in Urban Development.

Warwickshire: ITDG Publishing.

Servaes, J. \& Malikhao. P. 2008.

Development Communication Approaches in an International Perspective. In

Servaes, J (ed.) Communication for Development and Social Change, (pp.158-179).

London: SAGE .

Simtowe, F.,M. Zeller, \& A. Diagne. 2009

The Impact of Credit constraints on the adoption of hybrid maize in Malawi'.

Paper presented at the International Association of Agricultural Economists

Conferences, Beijing, China (16-22 August).

Smale, M., \& Phiri, A.(with contributions from G.A. Chikafa, P. W. Heisey).1998.

Institutional Change and Discontinuities in Farmers' Use of Hybrid Maize Seed and Fertilizer in Malawi: Findings from the 1996-97 CIMMYT/ MoALD

Survey (Working Paper 98-01).

http://ageconsearch.umn.edu/bitstream/7674/1/wp98sm04.pdf. (Accessed 11 May 2013)

Smale, M., (with Z.H.W. Kaunda, H.L. Makina, M.M. Mkandawire, M.N.S. Msowoya, D.J.E.K. Mwale, and P.W. Heisey).1991.

Chimanga Cha Makolo, Hybrids, and Composites: An Analysis of Farmers'

Adoption of Maize Technology in Malawi, 1989-91. CIMMY'T Economics

Working Paper 91/04. Mexico, D.F.: CIMMY'T.

http://repository.cimmyt.org/xmlui/bitstream/handle/10883/880/36521.pdf?s equence $=1$. (Accessed 12 January 2013)

Tufte, T. \& Mefalopulos, P. 2009.

Participatory Communication: A Practical Guide (Working Paper No.170). Washington: The World Bank

Veneklasen, L., \& Miller. V.2002.

Power and Empowerment. PLA Notes, 43: 39-41. 